\title{
"Crisis" versus Aesthetic in the Copernican Revolution
}

\section{Citation}

Gingerich, Owen. 1975. "Crisis" versus aesthetic in the Copernican revolution. Vistas in Astronomy 17(1): 85-95.

\section{Published Version}

doi:10.1016/0083-6656(75)90050-1

\section{Permanent link}

http://nrs.harvard.edu/urn-3:HUL.InstRepos:4258973

\section{Terms of Use}

This article was downloaded from Harvard University's DASH repository, and is made available under the terms and conditions applicable to Other Posted Material, as set forth at http:// nrs.harvard.edu/urn-3:HUL.InstRepos:dash.current.terms-of-use\#LAA

\section{Share Your Story}

The Harvard community has made this article openly available.

Please share how this access benefits you. Submit a story.

Accessibility 


\section{"Crisis" versus Aesthetic in the Copernican Revolution}

\section{OWEN GINGERICH}

\section{Smithsonian Astrophysical Observatory and Harvard College Observatory}

IN A chapter in The Structure of Scientific Revolutions entitled "Crisis and the Emergence of Scientific Theories", Thomas Kuhn states: "If awareness of anomaly plays a role in the emergence of phenomena, it should surprise no one that a similar but more profound awareness is prerequisite to all acceptable changes of theory. On this point historical evidence is, I think, unequivocal. The state of Ptolemaic astronomy was a scandal before Copernicus' announcement." A paragraph later he elaborates:

For some time astronomers had every reason to suppose that these attempts would be as successful as those that had led to Ptolemy's system. Given a particular discrepancy, astronomers were invariably able to eliminate it by making some particular adjustment in Ptolemy's system of compounded circles. But as time went on, a man looking at the net result of the normal research effort of many astronomers could observe that astronomy's complexity was increasing far more rapidly than its accuracy and that a discrepancy corrected in one place was likely to show up in another.

The existence of an astronomical crisis facing Copernicus in the early 1500 s is presupposed by one author after another; perhaps it is most vividly expressed by de Vaucouleurs, who writes:

The Ptolemaic system was finally overthrown as a result of the complexity which arose when an ever-increasing number of superimposed circles had to be postulated in order to

\footnotetext{
${ }^{1}$ Thomas S. Kuhn, The Structure of Scientific Revolutions, pp. 67-68, Chicago, 1962.
} 


\section{Omen Gingerich}

represent the ever-multiplying inequalities in the planetary motions revealed by observational progress. ${ }^{2}$

Nevertheless, my own researches have convinced me that this supposed crisis in astronomy is very elusive and hard to find, at least in the places where we are normally told to look. As a simple but powerful example of what I have in mind, let me cite the work of two leading ephemeris-makers of the sixteenth century, Johannes Stoeffler and Johannes Stadius.

Stoeffler was born in 1452 . When late in life he became professor of mathematics at Tübingen, he already enjoyed a virtual monopoly with the ephemerides prepared by himself and Jacob Pflaum; these had continued through 1531 those of Regiomontanus. At 'Tübingen he extended his calculations to 1551, and these were published there posthumously in $1531 .^{3}$

At about the same time that Stoeffler died (1530), Johannes Stadius was born (1527). In the 1560s Stadius taught mathematics at Louvain, and later he worked in Paris. Stadius was the first computer to adopt the Copernican parameters for a major ephemeris. ${ }^{4}$ His own tables were, in effect, the successors to Stoeffler's, and their users included Tycho Brahe.

In this modern age of refined planetary theory and of electronic computers, it has become possible to calculate with fair precision where the planets really were in the sixteenth century, and hence I have been able to graph the errors in the planetary positions predicted by Stoeffler and by Stadius. These error patterns are as distinctive as fingerprints and reflect the characteristics of the underlying tables. That is, the error patterns for Stoeffler are different from those of Stadius, but the error patterns of Stadius closely resemble those of Maestlin, Magini, Origanus, and others who followed the Copernican parameters (see Figs. 50 and 51 on p. 94). ${ }^{5}$

The first result of this comparison is the fact that the errors reach approximately the same magnitude before and after Copernicus. In the Regiomontanus and Stoeffler ephemerides, the error in longitude for Mars is sometimes as large as $5^{\circ}$. However, in 1625, the Copernican errors for Mars reached nearly $5^{\circ}$, as Kepler complained in the Preface to his Rudolphine Tables. ${ }^{6}$ And in Tycho's observation books, we can see occasional examples where the older scheme based on the Alfonsine Tables yielded better predictions than could be obtained from the Copernican Prutenic Tables. Now if the scandalous crisis of Ptolemaic astronomy was its failure to predict planetary positions accurately, Urania was left with nearly as much of a crisis on her hands after Copernicus.

Many simple historical accounts of the Copernican revolution emphasize not the accuracy but the simplicity of the new system, generally in contrast to the horrendous

${ }^{2}$ Gérard de Vaucouleurs, Discovery of the Universe, pp. 32-33, London, 1957.

${ }^{3}$ See Note A, pp. 91-92.

4 See Note B, p. 92.

${ }^{5}$ See Note C, p. 92.

${ }^{6}$ See Note D, pp. 92-93. 
complex scheme of epicycles-upon-epicycles supposedly perpetrated by preCopernican astronomers. This tale reaches its most bizarre heights in a recent Encyclopedia Britannica, ${ }^{7}$ where the article on astronomy states that by the time of Alfonso in the thirteenth century, forty to sixty epicycles were required for each planet! More typically, we find what Robert Palter has called the "80-34 syndrome"the claim that the simpler Copernican system required only thirty-four circles in contrast to the eighty supposedly needed by Ptolemy. ${ }^{8}$ The Copernican count derives from the closing statement of his Commentariolus: "Altogether, therefore, thirty-four circles suffice to explain the entire structure of the universe and the entire ballet of the planets." ${ }^{9}$ By the time Copernicus had refined his theory for his more mature De revolutionibus, he had rearranged the longitude mechanism, thereby using six fewer circles, but he had added an elaborate precession-trepidation device as well as a more complicated latitude scheme for the inner planets. Even Copernicus would have had difficulty in establishing an unambiguous final count. ${ }^{10} \mathrm{~A}$ comparison between the Copernican and the classical Ptolemaic system is more precise if we limit the count of circles to the longitude mechanisms for the (Sun), Moon, and planets: Copernicus requires 18, Ptolemy $15 .{ }^{11}$ Thus, the Copernican system is slightly more complicated than the original Ptolemaic system.

The 80-34 myth claims that the original simplicity of the Ptolemaic system was lost over the course of the ensuing centuries. "Theory patching was the order of the day", writes one recent author. The eighty circles presumably resulted from the piling of one epicycle on another, reminiscent of the lines

$$
\begin{aligned}
& \text { Great fleas have little fleas } \\
& \text { upon their backs to bite 'em, } \\
& \text { And little fleas have lesser fleas, } \\
& \text { and so ad infinitum. }
\end{aligned}
$$

${ }^{7}$ See Note E, p. 93.

${ }^{8}$ Robert Palter, "An approach to the history of early astronomy", History and Philosophy of Science, 1, 93-133 (1970). Palter traces the 80-34 myth back as far as Arthur Berry's A Short History of Astronomy (London, 1898).

"Edward Rosen, "Nicholas Copernicus, a biography", in his Three Copernican Treatises, 3rd ed., p. 90 (New York, 1971).

${ }_{10}$ According to Ernst Zinner, Entstehung und Ausbreitung der Copernicanischen Lehre, pp. 186-7 (Erlangen, 1943), Copernicus should have included precession, the regression of the lunar nodes, and the change of solar distance in his count in the Commentariolus, thus getting a total of thirty-eight circles. Arthur Koestler in The Sleepmalkers, pp. 572-3 (London, 1959), attempted to count the circles in De revolutionibus, but he overlooked the fact that Copernicus had by then replaced the so-called Túsi couple in the longitude mechanisms by an eccentric, thereby listing at least six unnecessary circles; on the other hand, he could have claimed that the motion of the apsidal lines for Mercury and the superior planets each required a circle.

${ }^{11}$ Copernicus replaced the Ptolemaic mechanism for varying the site of Mercury's orbit with a Tuusi couple, and he also accounted for the apsidal motion of the Earth's orbit with two circles. If the apsidal motions for Mercury and the superior planets are counted, then Copernicus required twenty-two circles for the motions in longitude. 


\section{Omen Gingerich}

Astronomers have been fond of this view, because of the parallel between epicycleson-epicycles and an analysis by Fourier series. ${ }^{12}$ Nevertheless, this contrast between the simplicity of the Copernican system and the complexity of the detailed Ptolemaic mechanisms proves to be entirely fictitious.

Consider Stoeffler once more, the successor of Regiomontanus and the most successful ephemeris-maker of his day. If improvements were available in a patchedup scheme of epicycles-on-epicycles, surely Stoeffler would have used them. Two extensive sets of calculations allowed me to investigate this possibility.

First, I recomputed the thirteenth-century Alfonsine Tables, showing that they are based on a pure Ptolemaic theory, that is, with an eccentric, equant and single epicycle for the superior planets. The parameters were almost all identical to those originally adopted by Ptolemy, but the precessional motion had been augmented by trepidation, an improvement irrelevant to the discussion of epicycles-on-epicycles. Second, I used the Alfonsine Tables to generate a daily ephemeris for three centuries; ${ }^{13}$ these positions agreed so closely with those published by Stoeffler that I am forced to conclude he used the unembellished Ptolemaic system, as transmitted through the Alfonsine Tables (Fig. 52, p. 95). ${ }^{14}$

Thus, this second result of investigating the ephemerides indicates that only a simple, classical Ptolemaic scheme was used for the prediction of planetary positions in 1500 . I am convinced that the complex, highly embroidered Ptolemaic system with all the added circles is a latter-day myth. To support my view, there are at least two more good arguments, although $I$ can mention them only in passing. First, the most sophisticated understanding of the Ptolemaic system in the fifteenth century is reflected in the tract against Cremonensis, ${ }^{15}$ in which Regiomontanus picks faults with an anonymous Medieval work, the Theorica Planetarum. One receives the impression here that in 1464 astronomers were once again just able to comprehend Ptolemy, but scarcely able to improve on his work. Second, the astonishing, almost

12 A recent letter to Physics Today (24, p. 11) remarked that 400 years ago the Physical Reviem might have been full of such papers as "A ten epicycle fit to the orbit of Mars", and a review article on radio galaxies in The Astronomical fournal, 77, p. 541, 1972, summarized with "The question is, "Are we drawing too many epicycles?" "

${ }^{13}$ E. Poulle and $O$. Gingerich, "Les positions des planètes au moyen âge: Application du calcul électronique aux tables Alphonsines", Comptes Rendus de l' Académie des Inscriptions et Belles Lettres, pp. 531-48, 1968.

${ }^{14}$ Recently, I found in the Badische Landesbibliothek in Karlsruhe what I believe to be Stoeffler's personal manuscript copy of these tables, which he may have used in calculating his ephemerides. It is Codex Ettenheim-Münster 33,93r-198r. I wish to thank the director, Dr. Kurt Hannemann, for showing me this manuscript. See Karl Preisendanz, Die Handschriften des Klosters Ettenheim-Münster, IX in Die Handschriften der Badischen Landesbibliothek in Karlsruhe, Wiesbaden, 1932.

${ }^{15}$ Johannes Regiomontanus, Disputationes contra Cremonensia deliramenta, Nuremberg, 1474 or 1475. According to Ernst Zinner, Leben und Wirken des Foh. Müller von Königsberg, 2nd ed., p. 335 (Osnabrück, 1968), Regiomontanus wrote the tract in August 1464. 
complete absence of recorded observations before 1450 again suggests that preCopernican astronomers had little basis for adding those mythical epicycles-onepicycles. I simply cannot believe Kuhn's statement that "as time went on, a man looking at the net result of the normal research effort of many astronomers could observe that astronomy's complexity was increasing far more rapidly than its accuracy and that a discrepancy corrected in one place was likely to show up in another". 1

I am willing to grant that Copernicus' cosmology represents, in a certain profound sense, a simplification, but I refuse to concede that the Ptolemaic theory had by the beginning of the sixteenth century reached a complex, patched-up state nearing collapse. In terms of the detailed mechanism for any particular planet, it would have been very difficult for Copernicus' contemporaries to distinguish between the two schemes on the basis of complexity.

Where, then, is the astronomical crisis that Copernicus faced? Kuhn goes on to say:

By the early sixteenth century an increasing number of Europe's best astronomers were recognizing that the astronomical paradigm was failing in application to its own traditional problems. That recognition was prerequisite to Copernicus' rejection of the Ptolemaic paradigm and his search for a new one. His famous preface still provides one of the classic descriptions of a crisis state. ${ }^{16}$

This preface is the last extant piece of Copernican prose, written just before the publication of his book. A polemical passage, it attempts to justify his radical departure from traditional cosmology and to protect his work from future detractors. If one believes astronomy was at the point of crisis, then it is perhaps possible to read it as a classic description of a crisis state.

On the other hand, I believe that an alternative reading is preferable. After criticizing the alternative system of homocentric spheres, and indirectly, Ptolemy's equant, Copernicus says:

Nor have they been able thereby to discern or deduce the principal thing-namely the design of the universe and the fixed symmetry of its parts. With them it is as though one were to gather various hands, feet, head and other members, each part excellently drawn, but not related to a single body, and since they in no way match each other, the result would be monster rather than man. ${ }^{17}$

This "fixed symmetry of its parts" refers to the fact that, unlike in the Ptolemaic scheme, the relative sizes of the planetary orbits in the Copernican system are fixed with respect to each other and can no longer be independently scaled in size. This is certainly one of the most striking unifications brought about by the Copernican

${ }^{16}$ Kuhn, op. cit., p. 69.

${ }^{17}$ N. Copernicus, De revolutionibus orbium coelestium, f. iii(v), Nuremberg 1543. Edward Rosen suggests for "certam symmetriam" the term "true symmetry". I believe that "fixed" conveys a slightly better nuance in this context. 


\section{Omen Gingerich}

system - what I would call a profound simplification. Clearly, this interlinking makes the unified man, and in contrast the individual pieces of Ptolemy's arrangement become a monster.

What has struck Copernicus is a new cosmological vision, a grand aesthetic view of the structure of the Universe. If this is a response to a crisis, the crisis had existed since A.D. 150. Kuhn has written that the astronomical tradition Copernicus inherited "had finally created a monster", but the cosmological monster had been created by Ptolemy himself.

In this view, there is no particular astronomical reason why the heliocentric cosmology could not have been defended centuries earlier, and it is in fact shocking that Copernicus, with the accumulated experience of fourteen more centuries, did not come up with a substantial advance in predictive technique over the well-honed mechanisms of Ptolemy. The debased positivism that has so thoroughly penetrated our philosophical framework urges us to look to data as the foundation of a scientific theory, but Copernicus' radical cosmology came forth not from new observations but from insight. It was, like Einstein's revolution four centuries later, motivated by the passionate search for symmetries and an aesthetic structure of the universe. Only afterward the facts, and even the crisis, are marshalled in support of the new world view. ${ }^{18}$

But why, if all this is true, did a Copernicus come in the sixteenth century, and not in the fourteenth or even the tenth century? Were the astronomical questions in Krakow in 1492 particularly conducive to challenging the old order? I have no doubt but that the growing problems of precession, trepidation, and the motion of the eighth sphere acted as a spur to Copernicus' thinking about astronomy. His attack on this problem demonstrates his unusual level of technical ability, which had certainly been rare in the Middle Ages. Copernicus' examination of precession may have led him to consider a moving Earth. ${ }^{19}$ Nevertheless, the heliocentric system is scarcely a necessary consequence of the observation of precession.

No, I believe that it was something outside astronomy in the European intellectual climate in the sixteenth century that set the stage for the introduction of a new paradigm; as Professor Benjamin Nelson put it in an earlier paper in this symposium -it had something to do with "societies, communities, and communications". In his words, the flowering of new world views must be considered within the context of complex sociocultural structures. The sixteenth century was manifestly an age of (1969).

${ }^{18}$ See Gerald Holton, "Einstein, Michelson, and the 'Crucial Experiment' ", Isis, 62, 133-97

${ }_{19} \mathrm{~J}$. R. Ravetz, in Astronomy and Cosmology in the Achievement of Nicolaus Copernicus (Wroclaw, 1965), argues that studies of precession may have led to the Copernican cosmology. L. Birkenmajer, in Mikolaj Kopernik (Krakow, 1900), suggested that the deficiencies in the Ptolemaic lunar model may have started Copernicus on the road to the heliocentric system. Important as these may have been in the development of Copernicus' technical proficiency, there is no convincing argument that these studies would have led to a Sun-centered cosmology. 
change. While Copernicus was a student at Krakow, Columbus set sail across an unknown ocean. The new explorations made Ptolemy's time-honored geography obsolete. Discoveries of classical authors brought in a new humanism with fresh Neoplatonic ideals. Even the traditional authority of the Church was to crumble before the challenge of Luther and the reformers.

A powerful catalyst for these changes was the explosive proliferation of printing. ${ }^{20}$ As a student in Krakow, Copernicus could secure and annotate his own printed set of Alfonsine Tables as well as Regiomontanus' Ephemerides. Later, probably in Italy, he obtained Regiomontanus' Epitome of Ptolemy's Almagest; the close paraphrases of many of its passages in the De revolutionibus show the formative role this book played in his researches. Still later, the first full printed Almagest of 1515 provided another useful source of data. ${ }^{21}$ Ultimately, it was the printed edition of his De revolutionibus that prevented his ideas from falling into oblivion.

In many ways, the world was ready for an innovative view of the cosmos. Copernicus, with both the intellect and the leisure to fashion a new cosmology, arrived on the scene at the very moment when the increased flow of information could both bring him the raw materials for his theory and rapidly disseminate his own ideas. An imaginative thinker striving to uncover fresh harmonies in the universe, he also achieved the technical proficiency to command respect for his mathematics and his planetary tables. One can easily argue that Copernicus was not the equal of Ptolemy or of Kepler in mathematics, although for his day he stood well above his contemporaries. Yet as a sensitive visionary who precipitated a scientific revolution, Copernicus stands as a cosmological genius with few equals. In celebrating his birth, we celebrate the man who, perhaps unwittingly, is the founder of modern science.

\section{Notes}

Note A. In 1474 in Nuremberg, Regiomontanus printed his own ephemerides for 1475 through 1506, and these were reissued by various printers, including Ratdolt in Venice. Stoeffler and Pflaum issued their ephemerides in Ulm in 1499 for the years 1499 to 1531 , with the title Almanach nova plurimis annis venturis inservientia, and these were repeatedly reissued by Liechtenstein in Venice. I have not yet ascertained if they recalculated the overlapping period from 1499 to 1506. Stoeffler's 1531 edition in Tübingen, with the title Ephemeridum opus, was edited by the successor to his professorial chair, Phillip Imsser; these tables were also promptly reprinted by Liechtenstein in Venice.

${ }^{20}$ See Owen Gingerich, "Copernicus and the impact of printing" on pp. 201-20 of this volume. See also E. L. Eisenstein, "The advent of printing and the problem of the Renasissance", Past and Present, no. 45, pp. 19-89 (1972).

${ }^{21}$ A detailed discussion of Copernicus' use of these books is found in L. Birkenmajer, Mikolaj Kopernik (Krakow, 1900). A useful list of books owned by, or available to, Copernicus is found in L. Jarzębowski's Biblioteka Mikolaja Kopernika (Toruń, 1971). An earlier list, of the Copernican books now found in Sweden, is E. Barwiński, L. Birkenmajer, and J. Los, Sprawozdanie z Poszukimań wo Szmecyi, pp. 94-119 (Krakow, 1914). 


\section{Open Gingerich}

Edward Sherburne gives a charming account of the death of Stoeffler in the biographical appendix to his The Sphere of Marcus Manilius (London, 1675), p. 46:

His death, or the occasion thereof at least, was very remarkable (if the Story be True). Having found by calculation, that upon a certain Day his life was like to be endangered by some ruinous accident, and the day being come, to divert his thoughts from the apprehension of the danger threatening him, he invites some Friends of his into his Study, where, after discourse, enticing into some dispute, he, to decide the controversie reaches for a Book, but the Shelf on which it stood being loose came down with all the Books upon him, and with its fall so bruised him, that he died soon after of the hurt, Voss. in Addend. ad Scient. Mathemat. But the whole Story of his Death, of which some make Calvisius the Author, is false by the Testimony of 7o. Rudolphus Camerarius Genitur. 69. Centur. 2. who had it from Andraas Ruttellius his Auditour; for he died of the Plague at Blabira Feb. 16. 1531 in the 78th year of his Age, happening (according to Calculation if you will believe it) from the Direction of $\bigcirc$ to $\sigma^{*}$.

Note B. Copernicus' own almanac was never printed and is now lost (see Edward Rosen, "Nicholas Copernicus, a biography", in his Three Copernican Treatises, pp. 374-5, 3rd ed., New York, 1971). Rheticus published an ephemeris for a single year, 1551, based on the tables in De revolutionibus. E. Reinhold published an ephemeris for 1550 and 1551, using his Copernican-based Tabulae Prutenicae (Tübingen, 1551); subsequent workers generally adopted Reinhold's tables as their avenue to the Copernican parameters. Stadius' Ephemerides novae (Cologne, 1556) included predictions for $1554-70$, and later editions carried the tables through 1600 . A posthumous edition went to 1606 , but the additional years were probably appended by the publisher from the Alfonsinebased ephemerides of Leovitius. Stadius published his own planetary tables, Tabulae Bergenses aequabilis et apparentis motus orbium coelestium (Cologne, 1560), but these were essentially a plagiarism of the Tabulae Prutenicae. Lynn Thorndike (A History of Magic and Experimental Science, vol. 5, pp. 303-4, New York, 1941) quotes Tycho Brahe's estimate of Stadius as having been "more facile than accurate", an opinion apparently shared by Maestlin and Magini, who eventually produced major alternative ephemerides of their own.

Note C. The ephemerides used for the figures are Johannes Stoeffler op. cit.; Cyprian Leowitz, Ephemeridum novum atque insigne opus ab anno 1556 usque in 1606 accuratissime supputatum, Augsburg, 1557; Johannes Stadius, Ephemerides novae et epactae ab anno 1554 ad annum I600, Cologne, 1570; Michael Maestlin, Ephemerides novae ex tabulis Prutenices anno 1577 ad annum 1590 supputatae, Tübingen, 1580; G. A. Magini, Ephemerides coelestium motuum secundum Copernici observationes supputatae, Venice, 1582. The comparisons were made against the computed longitudes in Bryant Tuckerman, Planetary, Lunar, and Solar Positions A.D. 2 to A.D. 1649, Memoirs of the American Philosophical Society, vol. 59, Philadelphia, 1964. Both figures were prepared by Barbara L. Welther.

Additional error graphs from sixteenth- and seventeenth-century ephemerides can be found in Owen Gingerich, "The theory of Mercury from Antiquity to Kepler", Actes du XII Congrès International d' Histoire des Sciences, vol. IIIA, pp. 57-64, 1971, and "Kepler's place in astronomy", Vistas in Astronomy, vol. 18, ed. A. and P. Beer, pp. 261-78, 1974.

Note D. "Johannes Kepler: Preface to the Rudolphine Tables", translated by Owen Gingerich and William Walderman, Quarterly Journal of the Royal Astronomical Society, 13, pp. 360-73, 1972; see especially p. 367.

Tycho frequently compared his own observations to the predictions from the Alfonsine and Copernican tables, usually to the advantage of Copernicus. A particularly favourable comparison occurred at the time of the great conjunction of Jupiter and Saturn in 1583 (see Fig. 51), although by 20 August, 1584, Tycho's comparison for Jupiter showed the two schemes equally in error, and by 21 December, 1586, the Alfonsine calculation was decidedly better, especially in latitude. Frequently, the Copernican latitudes proved inferior, even when the longitude excelled-for example, for Saturn on January 24, 1595. Tycho compared lunar positions in December 1594, and toward the end of the month the Alfonsine-based Leovitius ephemeris was superior. The most conspicuous 
Copernican errors found by Tycho occurred during the August opposition of Mars in 1593, exceeding $5^{\circ}$; this configuration repeated in 1625 when Kepler noted the large errors during the particularly close approach of Mars. Tycho's investigations are published in J. l.. E. Dreyer (ed.), Tychonis Brahe Dani Opera Omnia, 10-13, Copenhagen, 1923-6.

Nore E. "Astronomy. I. History of astronomy. B. Mediaeval astronomy", Encyclopcedia Britannica, vol. 2, p. 645, Chicago, 1969:

King Alfonso X of Castile kept a number of scholars occupied for ten years constructing tables (the Alphonsine tables, $c .1270$ ) for predicting positions of the planetary bodies. By this time each planet had been provided with from 40 to 60 epicycles to represent after a fashion its complex movement among the stars. Amazed at the difficulty of the project, Alfonso is credited with the remark that had he been present at the Creation he might have given excellent advice. After surviving for more than a millennium, the Ptolemaic system had failed; its geometrical clockwork had become unbelievably cumbersome and without satisfactory improvements in its effectiveness. 


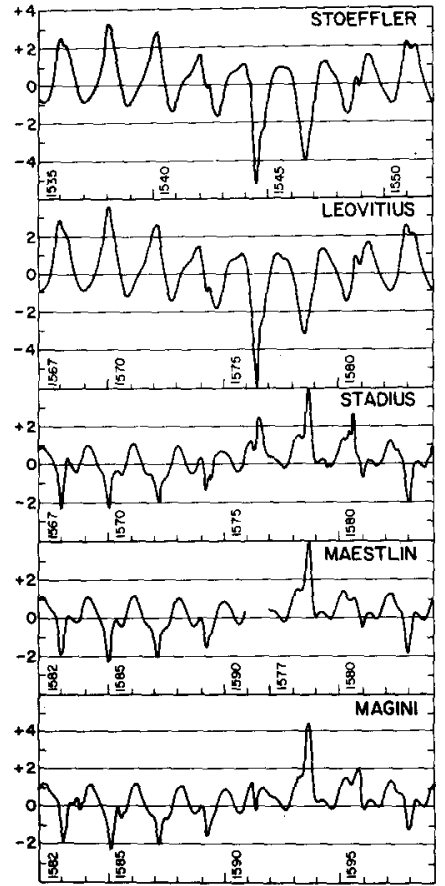

FIG. 51. Errors in predicted longitudes of Jupiter and Saturn near the time of their great conjunction in May 1583, a configuration closely observed by Tycho Brahe. There is evidently much computational noise in Stadius' positions for Jupiter. (Drawn by Barbara L. Welther.)
FIG. 50. The errors in the predicted longitude for Mars in the Alfonsine-based ephemerides of Stoeffler and Leovitius and three Copernicanbased ephemerides. Some of, but not all, the typographical or obvious computation errors of Stadius have been corrected. Note the close agreement in error patterns after intervals of 15 and 32 years. (Drawn by Barbara L. Welther.)

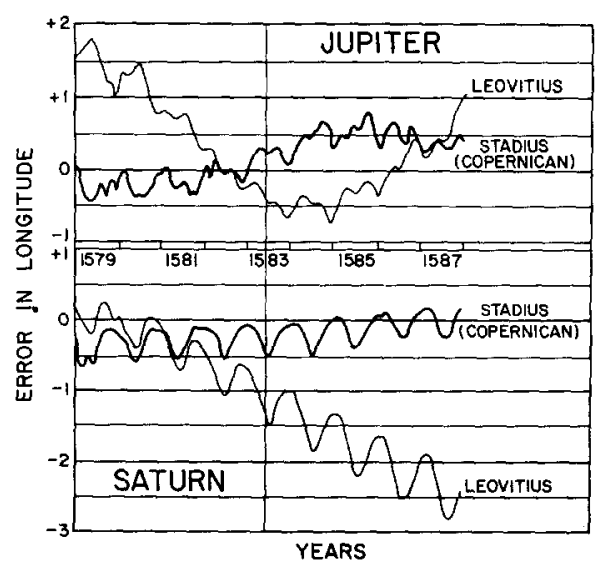




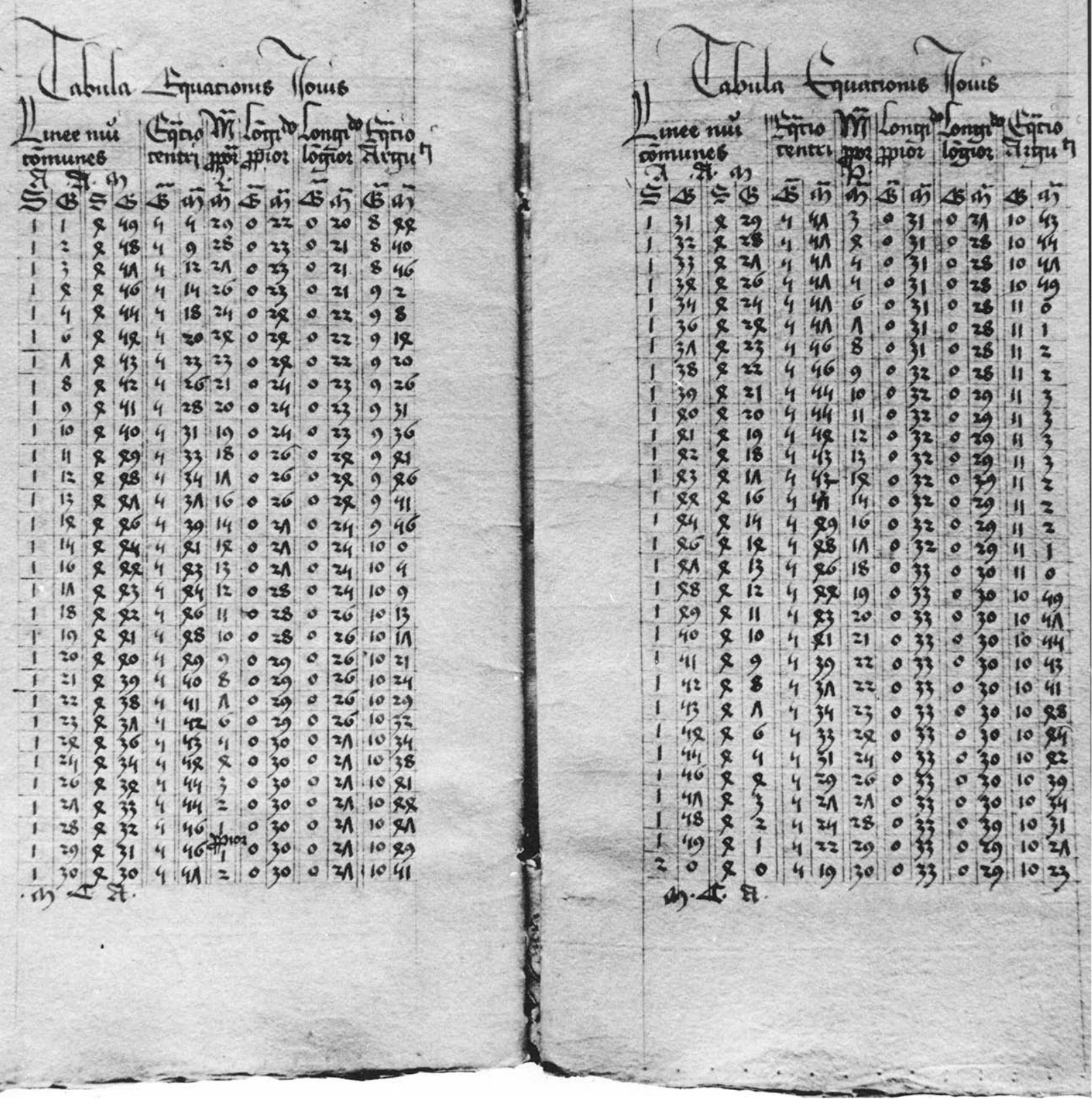

FIG. 52. A page from the Alfonsine Tables. (Photograph by Charles Eames.) Courtesy of the Lniversity Observatory Library, Uppsala. 